\title{
Resource intensity in global food chains: the Hot Spot Analysis
}

Originally published as:

Christa Liedtke, Carolin Baedeker, Sandra Kolberg, Michael Lettenmeier (2010):

Resource Intensity in global food chains: the Hot Spot Analysis

In: British Food Journal, Vol. 112 No. 10, 2010, pp. 1138-1159

DOI: $10.1108 / 00070701011080267$ 
Christa Liedtke ${ }^{\mathrm{a}^{*}}$, Carolin Baedeker ${ }^{\mathrm{a}}$, Sandra Kolberg ${ }^{\mathrm{a}}$, Michael Lettenmeier ${ }^{a}$

\section{Resource intensity in global food chains: the Hot Spot Analysis}

a Wuppertal Institute for Climate, Environment, Energy, Wuppertal, Germany

*Corresponding author: Christa Liedtke, Wuppertal Institute, Döppersberg 19, 42103 Wuppertal, Germany

E-mail: christa.liedtke@wupperinst.org

Phone: +49 202 2492-130

Fax: +49 020 2492-138 


\title{
Resource intensity in global food chains: the Hot Spot Analysis
}

\author{
Dr. Christa Liedtke ${ }^{1}$, Carolin Baedeker ${ }^{2}$, Sandra Kolberg ${ }^{3}$, and \\ Michael Lettenmeier ${ }^{4}$ \\ Wuppertal Institute, Wuppertal, Germany
}

Journal: British Food Journal

Manuscript Type: Research Paper in publication

Keywords: Sustainable value chain, Food, life-cycle-analysis, hot spot analysis, resource consumption, resource-efficiency

\footnotetext{
${ }^{1}$ corresponding author: christa.liedtke@wupperinst.org

2 carolin.baedeker@wupperinst.org

3 sandra.kolberg@wupperinst.org

${ }^{4}$ michael.lettenmeier@wupperinst.org
} 


\begin{abstract}
Purpose - The Hot Spot Analysis developed by the Wuppertal Institute is a screening tool focussing on the demand of reliable sustainability oriented decision making processes in complex value chains identifying high priority areas ("hot spots") for effective measures in companies.

Design/methodology/approach - The Hot Spot Analysis is a qualitative method following a cradle-to-cradle approach. With the examples of coffee and cream cheese hot spots of sustainability indicators throughout the entire life cycle are identified and evaluated with data from literature reviews and expert consultations or stakeholder statements. This paper focuses on the indicator resource efficiency as an example of how the methodology works.
\end{abstract}

Findings - The identified hot spots for coffee are the raw material procurement phase in terms of abiotic material, water and energy consumption, the production phase concerning biotic material and the energy consumption in the use phase. For cream cheese relevant hot spots appear in the raw material procurement phase in terms of biotic materials and water as well as biotic materials and energy consumption during the production phase.

Research limitations/implications - Life Cycle Analyses connected to indicators like resource efficiency need to be applied as consequent steps of a Hot Spot Analysis if a deeper level of analysis is eventually aimed at which is more cost and time intensive in the short term. The Hot Spot Analysis can be combined with other sustainability management instruments. 
Practical implications - Research and management can be directed to hot spots of sustainability potential quickly which pays off in the long term.

Originality/value - Companies can address sustainability potentials relatively cost moderately.

Keywords Sustainable value chain, life-cycle-analysis, hot spot analysis, resource consumption, resource-efficiency, food

Paper type Research paper with two case studies 


\section{Food industry and resource-efficiency}

The whole food sector is consuming huge amounts of resources. The food and drink sector accounts for about $15-30 \%$ of all environmental pressures (ETC-SCP, 2009). The production of food appears often to be less resource intensive compared to other industrial products, but especially in this industry increased complexity in production and transport structures goes together with higher resource intensity (Huff et al., 2006). But even though the agricultural industry and food as a field of needs have one of the highest environmental impacts, only a very limited number of detailed studies on single products or entire process chains are existing already. To name an exception a MIPS $^{5}$ study on natural resource consumption of Finnish households and its reduction has been conducted (Kotakorpi et al., 2008).

The following facts and numbers demonstrate the need for an increase in resource productivity in the food industry. By 2050, the world population might increase up to 9.2 billion people (Population Division of the Department of Economic and Social Affairs of the United Nations Secretariat, 2007). Due to this expansion, the demand for resources, especially for food products, will increase. The increase in food production and consumption as well as changes in nutrition patterns have significant influence on the environment and cause an urgent need for the establishment of more sustainable business strategies. The requirements for complex structural supply chains in the range of social (Mikkola, 2008), as well as eco-

$5 \quad$ MIPS $=$ Material Input per Service unit 
logical (Hahlbrock, 2009) interaction are of growing importance in sustainable development.

For instance, loss of soil is a consequence of environmental degradation, constituting a major factor for the agricultural industry and food production. The annual losses of fertile soil reach up to 25 billion tons (SchmidtBleek, 2009). In the past 20 years a surface of approximately one million square kilometres -equal to the size of Germany, the Benelux Countries, Austria and Switzerland- of productive land got lost due to desertification, the overuse of fertile soil, deforestation for firewood, overfertilization, animal breeding, droughts, operation of vehicles, wind and water erosions, the (expected) rise of the sea level and floods which are in turn due to rising temperatures, soil sealing and clear-cutting which lead to a reduced capacity for the soil to absorb water (Schmidt-Bleek, 2009). The production of meat and dairy products signifies another growing factor accelerating environmental degradation. The consumption of meat has increased fivefold since 1950 (World Watch Institute, 2006) which explains why animal breeding has a huge effect on the loss of productive land. This has led to an increasing environmental impact since the 20 billion farm animals produce a significant amount of emissions and - at the same time demand a high amount of productive land for fodder production. Besides that, the demand of agricultural surfaces for the production of one kilogramme of meat is three to ten times higher than for the production of one kilogramme of wheat (Hahlbrock, 2009). 
Besides the problem of decrease of productive land, which is accelerated by land use competitions especially due to the production of bio fuels, meat and the extension of infrastructures, the resource use along the various food-product-chains is extremely intensive. The following section provides an example of virtual water content of products in order to illustrate how intensive water use can be along the food-product chain.

"Human beings require approximately four litres of drinking water per day to live. However, 500 times that amount of water is used to produce the food that each one of us needs per day." (Schmidt-Bleek, 2009, p.119). The production of one kilogramme cereals ${ }^{6}$ consumes up to 1000 litres of water. However, about $40 \%$ of the cereals are used as fodder. Food and fodder production only has a share of $70 \%$ concerning water withdrawal (Hahlbrock, 2009). To produce a hamburger, 3500 to 7000 litres of green water are needed according to (Mauser, 2009) who refers to green water as water that is evaporated through vegetation. Hoekstra and Chapagain (2006) claim that the virtual water content of one hamburger is 2400 litres. The virtual water content of a product means the sum of the water used in the various steps of the life cycle.

The trends we are facing concerning food production and consumption outlined in the paragraphs above can be summarised as follows:

6 wheat, corn, rice 
$\circ$ The demand on productive land increases as the consumption of meat and dairy products per capita is rising and an increasing amount of land is used for other purposes than food production.

○ A growing population of up to 9.2 billion people on earth will need to be supplied sufficiently with food and water.

- The degradation of land will accelerate even more if sustainable concepts for food production and consumption will not be applied in the future.

The topic of resource productivity will be of increasing interest for business and politics already in the near future. "Resource-efficiency and resource productivity can be defined as efficiency, with which energy and material is used within the business sector, meaning the added value per unit resource input" (Commission of the European Communities, 2003). Beyond political objectives on the national and international level (Bundesregierung, 2002 and European Council, 2006), the topic resourceefficiency has already reached commerce and industry. The fundamental change of business that has taken place since the nineties has caused outsourcing processes of cost-intensive units into low-wage regions, especially developing countries and countries in transition. That implies an increasing number of people involved as well as a geographical extension of value chains (Schätzl, 2000). The definition of value chain here follows the suggestion of Porter (1996) saying that it includes the whole production process of a good, from resource extraction to consumption, compris- 
ing even all additional services, the further use and the recycling of a product as well as its waste treatment.

Due to the increased complexity and globalisation of production processes, the demand for management and controlling strategies is changing (Folkerts and Koehorst, 1998). Actors who deal with product chains, such as entrepreneurs, politicians, and retailers need to reply to an increased complexity in order to monitor all on-going processes with the objective of optimising value chains, e.g. in terms of resource use (Seuring and Westhaus, 2002). The paper at hand will therefore focus on complex global value chains and their designers such as producers, consumers and politicians influencing the resource use of the world supporting their possibilities to implement more sustainable production and consumption systems. To avoid risks for the different actors including companies and consumers, it is not sufficient anymore to organise corporate processes internally but the interorganisational relations within the value chain need to be considered too (Christopher, 1998). All relevant stakeholders have to be integrated in such a design process of global value chains. They need a status quo analysis that addresses the most important issues of such subsystems like coffee or cream cheese value chains and their implications on the eco- and social system along the production and consumption stages.

Thus, there is an increasing demand for simple, indicatory management and controlling instruments, that are based on aggregated information in order to show resource-efficiency potentials without being cost or time 
intensive (Schary and Skjoett-Larsen, 2001). Established methodologies like $\mathrm{LCA}^{7}$ are far too time and cost intensive for applying them in a company for all production and consumption processes (ISO 14041). In fact, there are a few LCA existing for products of the food industry ${ }^{8}$. Also for material-intensity analyses based on the MIPS-concept ${ }^{9}$, there are only some examples applied in entire food-product chains (Kaiser et al., 2008; Kauppinen et al., 2008a; Kauppinen et al., 2008b). In order to estimate the input-oriented impact on the environment caused by a product or service, MIPS indicates the quantity of resources ${ }^{10}$ required for this product or service. A MIPS analysis covers the entire life cycle of a product or service but is still less labour-intensive than a complete LCA (Ritthoff et al., 2002; Lähteenoja et al., 2006; Kuhndt, et al., 2002).

The few MIPS analysis and LCA studies covering the entire food-product chains aim at giving an overview about the relative material intensities of different areas within the food chain as well as demonstrating interdependencies between certain parameters.

Although the demand for specific analyses obviously exists, it seems in any case reasonable to identify hot spots along the whole value chain before applying a MIPS analysis or even a deeper LCA which are cost and time intensive and require expertise. To bring sustainability and resource management into corporate practice, a step-by-step approach has proven appropriate for a corporate context. As a first step, a Hot Spot Analysis

\begin{tabular}{ll}
\hline 7 & Life Cycle Assessment \\
8 & compare LCA Food Database \\
9 & MIPS = Material Input per Service unit \\
10 & named "materials" in the MIPS concept
\end{tabular}


should be applied (Kuhndt et al., 2002; Wallbaum and Kummer, 2006). This can be followed later on by a MIPS analysis, possibly including also other core indicators. A whole or segmental LCA approach can be applied at last, in case a more exact differentiation will be necessary, e.g. if detailed scenarios including also emissions and similar aspects are required. Every step needs to be concluded by "indicators for action" in order to create direct use for the respective company. A step-by-step approach will increase the data base and thus the ability to implement and improve sustainability management data and information systems. Focus can be various indicator sets, such as for instance, resource efficiency as is in the paper at hand, but also social or economic ones. Table I below compares the main characteristics of the Hot Spot Analysis, MIPS and LCA approaches. The Hot Spot Analysis explores the most relevant factors or phases influencing e.g. the indicator resource use in the life cycle or product chain with regard to sustainability according to available literature, expert consultations or stakeholder statements while MIPS looks at the physical material flows, i.e. the input side of production and consumption systems, aggregated flows of abiotics, biotics, top soil, water and air (oxygen), which are regarded as central background of environmental impacts, during the life cycle of a product or service. The LCA approach focuses on mainly emission- and energy-based environmental impacts during the life cycle such as global warming, acidification or eutrophication. The Hot Spot Analysis provides companies and perhaps their stakeholders with a rough overview over relevant aspects in a short period of time and is based on scientific publications. This requires knowledge of scientific literature. 
The Hot Spot Analysis does not offer quantitative productivity potentials. MIPS is often calculated on the basis of already existing average figures but a process specific calculation is also possible. In order to apply MIPS its concept needs to be understood. The calculation is relatively easy and allows a comparison between the options available and the investigation of consumption patterns. MIPS can be used as a basis for labelling and indices. Efficiency potentials of resources and costs can be calculated. But MIPS itself is costly. MIPS, as well as LCA need more time than the Hot Spot Analysis. LCA are based on existing data and process specific data which require a special software and knowledge of the product concerned. A detailed analysis of development options can be conducted which might lead to less environmental impact through the calculation of potentials but which is very expensive and complex.

\begin{tabular}{|c|c|c|c|}
\hline Methodology & $\begin{array}{l}\text { Hot Spot Analysis } \\
\text { (Kuhndt et al., } \\
\text { 2002; Wallbaum } \\
\text { and Kummer, 2006) }\end{array}$ & $\begin{array}{l}\text { MIPS (Material } \\
\text { Input per Service } \\
\text { unit) analysis } \\
\text { (Schmidt-Bleek, } \\
\text { 2007; Ritthoff et } \\
\text { al., 2002) }\end{array}$ & $\begin{array}{l}\text { Life Cycle Assess- } \\
\text { ment (LCA) } \\
\text { (ISO 14041) }\end{array}$ \\
\hline Main sources & & & \\
\hline Short description & $\begin{array}{l}\text { Elaboration of the } \\
\text { most relevant fac- } \\
\text { tors or phases influ- }\end{array}$ & $\begin{array}{l}\text { Analysis of the } \\
\text { physical material } \\
\text { flow inputs during }\end{array}$ & $\begin{array}{l}\text { Analysis of mainly } \\
\text { emission- and en- } \\
\text { ergy-based envi- }\end{array}$ \\
\hline
\end{tabular}


Resource intensity in global food chains: the Hot Spot Analysis

\begin{tabular}{|c|c|c|c|}
\hline & $\begin{array}{l}\text { encing sustaina- } \\
\text { bility indicators } \\
\text { such as resource } \\
\text { use in the life cycle } \\
\text { / product chain. }\end{array}$ & $\begin{array}{l}\text { the life cycle of a } \\
\text { product or service. } \\
\text { Material flows are } \\
\text { understood as the } \\
\text { central background } \\
\text { of environmental } \\
\text { impacts. }\end{array}$ & $\begin{array}{l}\text { ronmental impacts } \\
\text { during the life cy- } \\
\text { cle. }\end{array}$ \\
\hline Aspects covered & $\begin{array}{l}\text { Sustainability as- } \\
\text { pects of different } \\
\text { life cycle phases, } \\
\text { according to avail- } \\
\text { able literature, ex- } \\
\text { pert consultations } \\
\text { or stakeholder } \\
\text { statements. }\end{array}$ & $\begin{array}{l}\text { Input side of pro- } \\
\text { duction and con- } \\
\text { sumption systems, } \\
\text { aggregated flows of } \\
\text { abiotics, biotics, top } \\
\text { soil, water and air } \\
\text { (oxygen). }\end{array}$ & $\begin{array}{l}\text { Different envi- } \\
\text { ronmental impacts } \\
\text { like energy use, } \\
\text { global warming, } \\
\text { acidification, eu- } \\
\text { trophication, etc. }\end{array}$ \\
\hline Level of depth & $\begin{array}{l}\text { Rough overview } \\
\text { over relevant sus- } \\
\text { tainability aspects. }\end{array}$ & $\begin{array}{l}\text { Often calculated on } \\
\text { the basis of existing } \\
\text { average figures but } \\
\text { process-specific } \\
\text { calculation pos- } \\
\text { sible. }\end{array}$ & $\begin{array}{l}\text { Calculated on the } \\
\text { basis of existing } \\
\text { data bases and/or } \\
\text { process-specific } \\
\text { data. }\end{array}$ \\
\hline $\begin{array}{l}\text { Origin of data } \\
\text { used }\end{array}$ & $\begin{array}{l}\text { Scientific publica- } \\
\text { tions. }\end{array}$ & $\begin{array}{l}\text { Published LCA and } \\
\text { other studies aver- } \\
\text { age material in- } \\
\text { tensity coefficients } \\
\text { or process-specific } \\
\text { information. }\end{array}$ & $\begin{array}{l}\text { Published LCA and } \\
\text { other studies data- } \\
\text { base and/or pro- } \\
\text { cess-specific emis- } \\
\text { sion data. }\end{array}$ \\
\hline $\begin{array}{l}\text { Suitability to } \\
\text { companies }\end{array}$ & $\begin{array}{l}\text { Requires know- } \\
\text { ledge of scientific } \\
\text { literature. Provides }\end{array}$ & $\begin{array}{l}\text { Requires under- } \\
\text { standing of MIPS } \\
\text { concept. Relatively }\end{array}$ & $\begin{array}{l}\text { Requires special } \\
\text { software and de- } \\
\text { tailed background }\end{array}$ \\
\hline
\end{tabular}


Resource intensity in global food chains: the Hot Spot Analysis

\begin{tabular}{|c|c|c|c|}
\hline & $\begin{array}{l}\text { an overview of rel- } \\
\text { evant aspects of the } \\
\text { product chain. Does } \\
\text { not offer quantita- } \\
\text { tive productivity } \\
\text { potentials. }\end{array}$ & $\begin{array}{l}\text { easy calculation } \\
\text { possible using e.g. } \\
\text { excel sheets. Pro- } \\
\text { vides a useful com- } \\
\text { parison between } \\
\text { different options } \\
\text { and phases of the } \\
\text { value chain. Re- } \\
\text { source and cost } \\
\text { efficiency poten- } \\
\text { tials can be calcu- } \\
\text { lated (Beucker, et } \\
\text { al., 2004). }\end{array}$ & $\begin{array}{l}\text { information on the } \\
\text { product studied. } \\
\text { Can provide a de- } \\
\text { tailed analysis of } \\
\text { specific develop- } \\
\text { ment options in } \\
\text { processes and pro- } \\
\text { duct chains. Poten- } \\
\text { tials for less envi- } \\
\text { ronmental impacts } \\
\text { can be calculated. }\end{array}$ \\
\hline $\begin{array}{l}\text { Suitability to } \\
\text { SMEs }\end{array}$ & $\begin{array}{l}\text { Relatively easy. } \\
\text { Requires time and } \\
\text { knowledge of sci- } \\
\text { entific literature. }\end{array}$ & $\begin{array}{l}\text { Relatively easy but } \\
\text { may require more } \\
\text { time in case of } \\
\text { complex products } \\
\text { or less known ma- } \\
\text { terials (depending } \\
\text { on the level of de- } \\
\text { tail), and relatively } \\
\text { less basic calcula- } \\
\text { tion knowledge and } \\
\text { information from } \\
\text { inside and outside. }\end{array}$ & $\begin{array}{l}\text { Relatively complex } \\
\text { and time intensive, } \\
\text { requires special } \\
\text { software and de- } \\
\text { tailed background } \\
\text { information from } \\
\text { inside and outside. }\end{array}$ \\
\hline $\begin{array}{l}\text { Suitability for } \\
\text { consumer infor- } \\
\text { mation }\end{array}$ & $\begin{array}{l}\text { Can be used to } \\
\text { separate big and } \\
\text { small issues from } \\
\text { each other but not }\end{array}$ & $\begin{array}{l}\text { Understandable } \\
\text { concept. Very suit- } \\
\text { able for comparison } \\
\text { of product groups }\end{array}$ & $\begin{array}{l}\text { Direct use would be } \\
\text { too complex. Can } \\
\text { be used as a basis } \\
\text { for labelling or in- }\end{array}$ \\
\hline
\end{tabular}




\begin{tabular}{|l|l|l|l|}
\hline for comparing pro- & or consumption & dices but remains \\
& ducts. & patterns to each & cost intensive. \\
& other. In principle & \\
& applicable for pro- & \\
& duct-specific in- & \\
& formation but & \\
& costly. Can be used & \\
& as a basis for label- & \\
& ling or indices. & \\
\hline
\end{tabular}

Table I. Main features of the approaches of Hot Spot Analysis, MIPS analysis and LCA for the identification of resource use and environmental impacts during the life cycle of products or services

The authors of this paper argue that the Hot Spot Analysis is very suitable for companies and relevant actors in order to detect potential hot spots of resource intensity along the value chain. Compared to MIPS and LCA it is a feasible approach with regard to costs and time. Companies often do not have the financial and time resources to apply MIPS and LCA and can easily start with the Hot Spot Analysis. In case a deeper level of analysis is pursued MIPS and LCA should be applied as consequent steps. Below a detailed explanation on the methodology of the Hot Spot Analysis is given in the next section elaborating on the advantages and disadvantages of the Hot Spot Analysis.

\section{The methodology of the Hot Spot Analysis}

The introduction of the Hot Spot Analysis by the Wuppertal Institute (Kuhndt et al., 2002;Wallbaum and Kummer, 2006) intends to be a qualitative assessment instrument that estimates the resource-intensity or other indicator areas of a product along its value chain. Other indicators could 
be applied gradually, such as economic or social ones. The main objective of a Hot Spot Analysis is to identify central peaks of resource use or sustainability issues along the whole value chain quickly, reliably and lifecycle-phase-specifically. The use of abiotic material ${ }^{11}$, biotic material ${ }^{12}$, water and energy is analysed for the life cycle phases' raw material procurement, production, use and waste treatment. Thus, the relative resource use of the respective life cycle phase becomes obvious as well as the extent of specific resources consumed along the value chain. Those "peaks" in consumption identified are defined as hot spots. It needs to be considered though that high resource consumption is not equivalent to a high saving potential. For a more specific analysis of resource-saving potentials an additional instrument should be introduced after the Hot Spot Analysis that is MIPS, LCA or other instruments.

A Hot Spot Analysis is performed in three steps:

1. Estimation of sustainability topics within a life-cycle phase (e.g. absolute resource-intensity within each phase)

2. Evaluation of these topics between the life-cycle phases (relative resource intensity of resource categories along the life-cycle)

3. Identification of hot spots by an integrated analysis of step 1 and 2

Scientific publications that provide facts about the resource-intensity in the whole value chain or parts of it are the basis for the analysis in step one and two. LCA studies - if existing - are of special interest. But these

11 non-renewable resources like mineral raw materials and fossil fuel

12 renewable resources like vegetable biomass from cultivation, plants and animals 
studies don't reflect the specific situation of the regarded value chain but use the information of existing, not in all areas relevant studies and LCAs so that puzzle parts are used of the whole picture to get a first estimation about relevant topics, summarize the information, structure and evaluate it concerning the investigated product chain. One of the limitations of the Hot Spot Analysis is that it is based on existing studies or parts of it. In the food sector, for instance, it might be difficult to find LCA studies. A multitude of data of various institutions is not consistent and clearly accessible. Nevertheless there is a huge amount of available literature or expert and stakeholder knowledge which can be made use of and therefore the Hot Spot Analysis is still a very useful tool to explore hot spots of resource intensity along the whole life cycle of a product. The assessment of the resource-intensity is done according to a scale from „high“ (3 points) to „low“ (1 point). The Hot Spot Analysis considers the resource consumption directly connected to the product or service, its raw materials and intermediate goods. Materials not directly connected to the product (e.g. packaging material or the maintenance of production or transportation machines) are not part of the analysis in the first step. If results exist that indicate that parts of them are important they could be flexibly included. But the first objective for analysis is the area where the actors can act and influence the sustainability directly. Therefore the decision makers get information to improve their hot spots gradually - first for the relevant need for action in the own value chain, and second if relevant in the process environment (e.g. relevant logistic problems of coffee products transporting by airplane instead of ships). Table II and Figure I show the 
three steps of the assessment of an imaginary product to introduce the methodology of the Hot Spot Analysis which can be used for orientation for further Hot Spot Analyses. The two case studies on coffee and cream cheese are supposed to substantiate the methodology in concrete examples taken from the food sector. The choice of coffee and cream cheese will be explained more in detail.
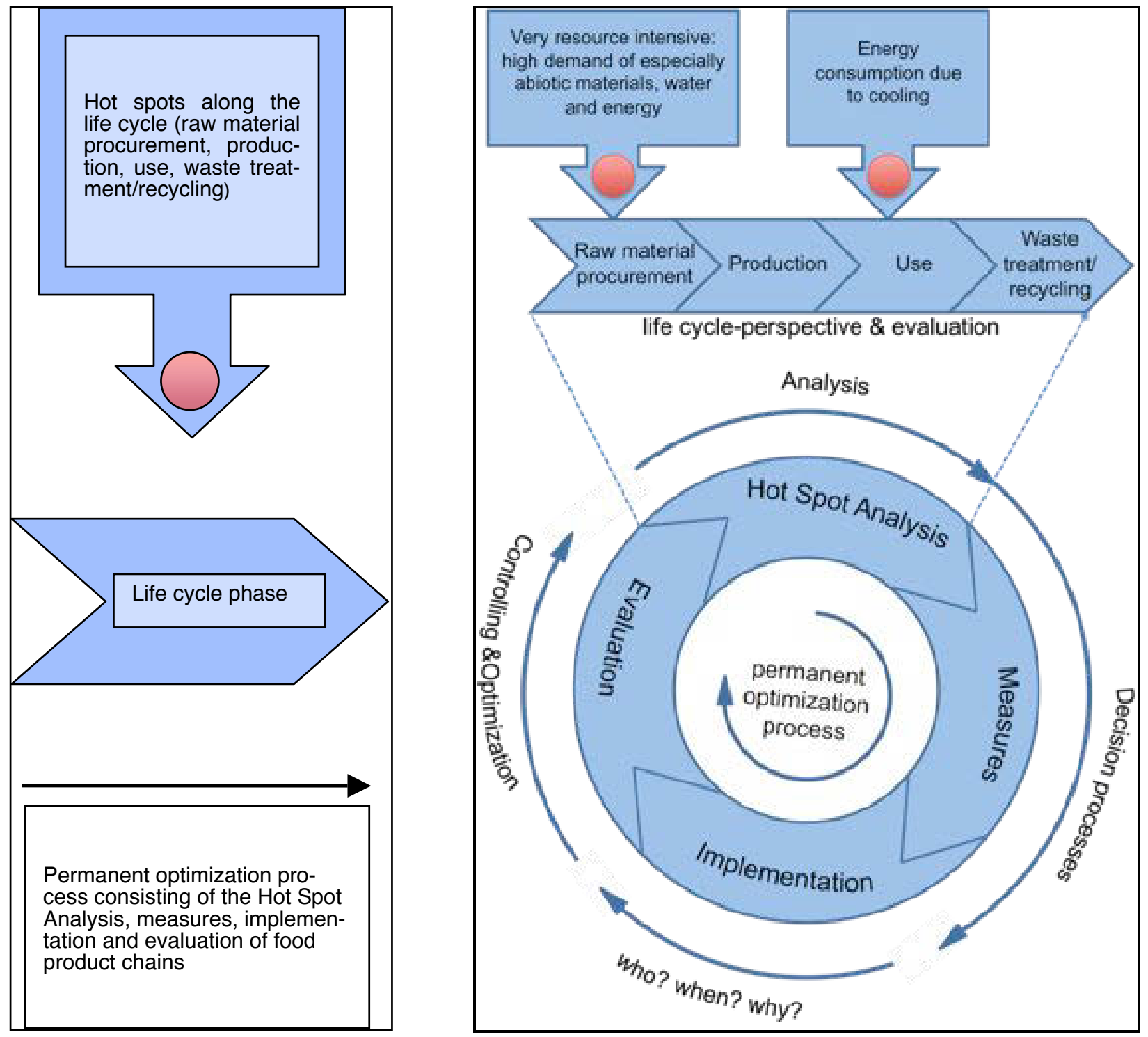

Figure I. Hot Spots: Exemplarily for a typical food chain, based on the imaginary product Identification of hot spots along the whole life cycle chain as part of a permanent optimization process consisting of the Hot Spot Analysis, measures, implementation and evaluation of instruments for food product chains based on the imaginary product 
In step one, the raw material procurement phase of an imaginary product is defined by a high extent of abiotic ${ }^{13}$ materials and energy, while in the production phase a high amount of water consumption is obvious and the consumption phase is characterised by high water and energy consumption. Although the energy consumption is considered to be high in two phases, this does not mean that their absolute value is comparable, because only an estimation of the relative evaluation within the respective lifecycle phase is done.

In order to compare the amount of resource consumption of one phase to another one, step two is performed. As there are only limited data for most products and services, the resource categories abiotic materials, biotic materials, water and energy cannot be applied like in step one. Thus, the aggregation of two categories "non-energetic"14 resources and "energy" is necessary. Table II shows how the assessment is supposed to look like. This example shows a high relevance of raw materials for the nonenergetic resources and of the use phase for the energy consumption.

\footnotetext{
13 non-renewable resources like mineral raw materials and fossil fuel
}

14 biotic and abiotic materials and water 


\begin{tabular}{|c|c|c|c|c|}
\hline \multicolumn{5}{|c|}{ Hot Spot Analysis of an imaginary product. } \\
\hline \multicolumn{5}{|c|}{ Step 1: Assessing the resource-intensity within each life cycle phase. } \\
\hline $\begin{array}{l}\text { Resource } \\
\text { category }\end{array}$ & $\begin{array}{l}\text { Raw } \\
\text { material } \\
\text { procure- } \\
\text { ment }\end{array}$ & Production & Use & $\begin{array}{l}\text { Waste } \\
\text { treatment }\end{array}$ \\
\hline Abiotic material $^{15}$ & 3 & 1 & 2 & 2 \\
\hline Biotic material $^{16}$ & 1 & 2 & 1 & 2 \\
\hline Water & 2 & 3 & 3 & 1 \\
\hline Energy & 3 & 1 & 3 & 1 \\
\hline
\end{tabular}

Step 2: Assessing the resource-intensity between the different life cycle phases.

\begin{tabular}{|l|l|l|l|l|}
\hline \multicolumn{1}{|c|}{ Life cycle phase } & $\begin{array}{l}\text { Raw } \\
\text { material } \\
\text { procure- } \\
\text { ment }\end{array}$ & Production & Use & $\begin{array}{l}\text { Waste } \\
\text { treatment }\end{array}$ \\
\hline Non-energetic & 3 & 1 & 1 & 2 \\
\hline Energy & 2 & 2 & 3 & 1 \\
\hline
\end{tabular}

Step 3: Identification of hot spots on the basis of steps 1 and 2.

\begin{tabular}{|c|c|c|c|c|}
\hline $\begin{array}{l}\text { Resource } \\
\text { Category }\end{array}$ & $\begin{array}{l}\text { Raw } \\
\text { material } \\
\text { procure- } \\
\text { ment }\end{array}$ & Production & Use & $\begin{array}{l}\text { Waste } \\
\text { treatment }\end{array}$ \\
\hline Abiotic materials ${ }^{9}$ & 9 & 1 & 2 & 4 \\
\hline Biotic materials $^{10}$ & 3 & 2 & 1 & 4 \\
\hline Water & 6 & 3 & 3 & 2 \\
\hline Energy & 6 & 2 & 9 & 1 \\
\hline
\end{tabular}

Table II. Allocation of assessment points based on the extent of resource and energy consumption in the respective life-cycle phase (step 1) and by analysing the relevance of the phases to each other (step 2). In step 3, the results of steps 1 and 2 are multiplied by each other so that the hot spots can be defined (scores of 6 and 9 points, adapted from Kuhndt, et al., 2002; Wallbaum and Kummer, 2006)

The hot spots are identified in the concluding step three. For a better visibility of the hot spots, the scores of steps one and two are multiplied by each other. The resource categories abiotic materials, biotic materials and water from step one are multiplied with the evaluation factor ,non-

\footnotetext{
15 non-renewable resources like mineral raw materials and fossil fuel

16 renewable resources like vegetable biomass from cultivation, plants and animals

9 non-renewable resources like mineral raw materials and fossil fuel

10 renewable resources like vegetable biomass from cultivation, plants and animals
} 
energetic", the category energy with the factor energy. For example, in the column raw material procurement the scores from step one, i.e. abiotic material (3), biotic material (1), water (2) and energy (3) are multiplied by the respective life-cycle evaluation factor from step two, i.e. (3) for nonenergetic resources and (2) for the category energy. The result of the multiplication (still on the column raw material procurement) appears as

- abiotic materials $3 \times 3=9$,

- biotic materials $1 \times 3=3$,

- $\quad$ water $2 \times 3=6$ and

- $\quad$ energy $3 \times 2=6$.

Hot spots are the fields with a result of six to nine points. In that way an overview of the most important life cycle phases regarding resource intensity can be generated for any value chain. As mentioned earlier, with this method, no productivity potentials are identified. Figure I visualises the approach of the Hot Spot Analysis exemplarily for a food product chain based on the imaginary product. Hot spots along the whole life cycle chain are identified as part of a permanent optimization process consisting of the Hot Spot Analysis, measures, implementation and evaluation of sustainability instruments. Hot spots are the red circles, which are explained more in detail in the blue arrows in which these circles are integrated. The arrows point to the specific life cycle phase where the hot spots occur. The raw material procurement phase is very resource intensive since a high demand of abiotic materials, water and energy have been identified as part of the Hot Spot Analysis. The use phase is very energy intensive due to cooling and storage of the imaginary product. The Hot Spot Analysis is only part of a permanent optimization process as visualised in the bigger circle. In the next phase measures have to be implemented in the decision 
processes in turn resulting in the actual implementation phase which deals with the stakeholders involved, time frames and reasons for implementation. The evaluation phase follows after the other three phases dealing with controlling and optimization of the measures of the decision processes and the implementation phases. For reaching successful and sustainable improvements it is important to keep in mind permanent optimization processes in a cradle to cradle approach expressed in the choice of a circle for this figure. Further explanations can be found in the caption above.

The following sections introduce the hot spot analysis applied in the case studies on coffee and cream cheese. These products have been chosen since they represent a German and a non-European product (cream cheese and coffee) from the food sector which contributes essentially to environmental degradation as outlined in the introduction. Coffee has been chosen because it is a popular product for a broad public and therefore promising to communicate the results. Coffee has one of the biggest shares in fair traded food which accounts for an increased alertness of consumers regarding this product. The consumption of coffee is bound to lifestyles and trends which is why it enables a tight link to the discussion of sustainable consumption. Coffee is an agricultural product with only a marginal upgrading process but must be imported from oversea and it is a growing product area concerning lifestyle behaviour and feeling (different sorts of drinking preparation). As explained previously meat and dairy products are extremely resource intensive which is why a case study of cream cheese is a valuable example for a Hot Spot Analysis. Cream cheese is an 
upgraded milk product which is more resource intensive in the upgraded stages compared to the first stage of raw milk, but is coming from livestock and therefore a highly resource inefficient product like meat. Household studies have shown that coffee and dairy products are relevant products that show specific consumption behaviour of different households in different social milieus (highly income/education households use a variety of highly upgraded coffee products with sophisticated and luxurious coffee machines and diary products instead of meat, lower income/education households consume less sophisticated coffee and eat more meat (Kotakorpi et al., 2008) The overall result is that the eco-oriented household consumes more resources having more eco-efficient strategies and the eco-afar households consume eco-inefficiently, but altogether more resource-efficiently. Therefore both products are highly relevant and core indicators for developing sustainable household behaviour strategies and patterns. Social responsibility in the interaction of each individual stakeholder involved plays an essential role in sustainable development (Rimmington et al., 2006).

\section{The case studies on coffee and cream cheese}

\subsection{The Hot Spot Analysis of coffee}

For the Hot Spot Analysis along the life cycle of coffee, the resources needed to produce packaging or marketing material as well as such for production plants, transport vehicles and machines are not considered since their environmental impact is minimal compared to others.(Kuhndt et al., 2002;Wallbaum and Kummer, 2006; Kaiser et al. 2008). Transpor- 
tation and logistic processes are not presented as single phases but the resources connected to transportation will be accounted in the respectively following life-cycle phase. For example, the transport of coffee beans to the processing plant is allocated to the production phase and the transport of the completed product to the retailer or consumer is allocated to the use phase.

The following paragraph explains the resource consumption in the life cycle phases of coffee more in detail. Existing scientific studies (structured in life-cycle phases) have been investigated in order to constitute which of the resource categories distinguished between abiotic (A), biotic (B), water (W) and energy (E) are most relevant per life-cycle phase. Table III, summarises the results below.

The energy consumption caused by using agrochemicals and the drying process of the beans is the one most relevant within the phase of raw material procurement, followed by the consumption of abiotic materials and water. The agrochemicals have to be considered here as pre-products of coffee and are therefore within the boundaries of the system. In the past decades, intensive monocultivation has expanded which implies an increase of agrochemicals (fertiliser, pesticides) that lead to higher harvests (WRI/UNDP, 1998; Rice and McLean , 1999). Especially for the production of artificial fertilisers a lot of energy and raw materials are needed. According to a study from Costa Rica, the percentage of energy spent to produce fertilisers reaches up to $69 \%$ of the overall energy needed in the coffee production process. Depending on the procedure, additional energy 
consumption can result from the drying process. The coffee trees face more often vermin or diseases in tropical or subtropical than in moderate climate conditions (Deutscher Kaffeeverband, 2005). Therefore intensive protection is required. Coffee-monocultures depend on water systems to some extent. In case the method of the so-called "wet treatment" is chosen, a massive amount of preferably pure spring water is consumed. The estimation of this amount differs from 40.000 to 70.000 1/t (EDE, 2001) and 130.000 to 150.000 1/t for raw coffee (Deutscher Kaffeeverband, 2005). Compared to systems cultivating in the shadow, the degradation of soil is much higher in monocultures. According to studies undertaken in Central America, the degradation is increasing while switching to mono cultures (EDE, 2001).

The production phase comprises the transport of the beans to the roaster as well as the roasting process. From the perspective of resource use, the coffee beans themselves are the most relevant, followed by the energy consumption. The coffee beans are the most important raw material in that phase, since the final product consists mainly of milled coffee beans. The transportation itself is connected to relatively low energy consumption, because it happens to be a mass product and it gets therefore mainly shipped (Wolters, 2001). The roasting process is connected to water and energy consumption, which is not estimated that high though (Diers et al., 1999). The amount of energy utilized increases significantly if instead of coffee powder instant coffee is analysed. Comparing the demand on en- 
ergy for different food products, instant coffee reaches up to first position with $18948 \mathrm{kcal} / \mathrm{kg}$ (Lake and Pagan, 1999).

The use phase starts with the transportation of coffee from the processing plant via the retailer to the consumer. Most relevant in that phase is the energy consumption during transport and storage within the households according to a Product Life-Cycle Analysis of vacuum packaged coffee (Diers et al., 1999). Other scholars argue that the energy demand to prepare coffee has the biggest influence in the use phase (Wolters, 2001). The consumption of water is negligible.

For the waste treatment phase the LCA mentioned above concludes that filter and coffee grounds are more relevant than the packaging (Diers et al., 1999). Packaging and filter are not part of the analysis because of their lower relevance per $\mathrm{kg}$ coffee or service unit (drinking a cup of coffee). The resource consumption connected to the coffee ground is considered to be rather low and is therefore not considered in the following anymore (Diers et al., 1999; Kotakorpi, et al., 2008).

\begin{tabular}{|l|l|}
\hline Raw material procurement & Relevance \\
\hline The use of agrochemicals (fertiliser, pesticides) & $\mathrm{A}^{17}$ \\
\hline $\begin{array}{l}\text { The production of artificial fertilisers and the drying process consume } \\
\text { huge amounts of energy and raw materials }\end{array}$ & \\
\hline Protection against vermin or diseases & $\mathrm{A}, \mathrm{E}$ \\
\hline
\end{tabular}

$17 \quad$ Abiotic material

18 Energy 
Resource intensity in global food chains: the Hot Spot Analysis

\begin{tabular}{|l|l|}
\hline Water systems & $\mathrm{W}^{19}$ \\
\hline If the "wet treatment" is chosen a massive amount of (preferably) pure & $\mathrm{W}$ \\
\hline spring water is consumed & \\
\hline Especially in monocultures a degradation of soil is constituted & $\mathrm{A}$ \\
\hline Assigned resource intensity in points for the raw material procurement phase: \\
\hline
\end{tabular}

\begin{tabular}{|c|c|}
\hline Production & Relevance \\
\hline Mainly coffee beans & $\mathrm{B}^{20}$ \\
\hline The transportation consumes relatively low energy & $\mathrm{E}$ \\
\hline The roasting process spends a relatively low amount of energy and water & $\mathrm{W}, \mathrm{E}$ \\
\hline Instant coffee spends significantly more energy than coffee powder & $\mathrm{E}$ \\
\hline \multicolumn{2}{|l|}{ Assigned resource intensity in points for the production phase: } \\
\hline A: 1 (low), B: 3 (high), W: 1 (low), E: 2 (medium) & \\
\hline
\end{tabular}

\begin{tabular}{|l|l|}
\hline Use & Relevance \\
\hline Energy consumption during transport and storage most relevant & E \\
\hline Transportation mostly for purchasing food & E \\
\hline Energy needed to prepare coffee has the biggest influence & E \\
\hline transportation by car & \\
\hline A: 1 (low), B: 1 (low), W: 2 (medium), E: 3 (high) & \\
\hline
\end{tabular}

\begin{tabular}{ll}
\hline 19 & Water \\
20 & Biotic material
\end{tabular}




\begin{tabular}{|l|l|}
\hline Waste treatment & Relevance \\
\hline Resource consumption is rather low and therefore irrelevant & - \\
\hline Assigned resource intensity in points for the waste treatment phase: \\
A: 1 (low), B: 1 (low), W: 1 (low), E: 1 (low)
\end{tabular}

Table III. Central results of scientific studies on life cycle aspects of coffee, by life cycle phases and with indication of relevance for the resource categories abiotic (A), biotic (B), water (W) and energy (E) (adapted from Kuhndt, et al., 2002;Wallbaum and Kummer, 2006)

For the Hot Spot Analysis of coffee, a summarising assessment of the resource consumption as described above and summarised in Table III will be done, first within each life-cycle phase (Table IV, step one). In order to get the full picture, the relevance of the phases towards each other has to be considered (step two).

Step two in Table IV visualizes qualitatively the relevance for resource intensity in the whole life cycle. For the assessment of the relevance of singular life cycle phases to each other in step two (Table IV), results from LCA and similar studies which consider the whole life cycle are used. The conclusion drawn from the studies of Wolters (2001) and Diers et al. (1999) is that the raw material procurement phase is the most intensive one both for the energetic (energy) as well as for the non-energetic resources (abiotic materials, biotic materials, water). For both resource categories non-energetic and energetic 3 points are assigned for the raw material procurement phase which expresses a high relevance compared to the other life cycle phases. After that the production phase is following. 2 points are assigned for both energetic and non-energetic resource catego- 
ries indicating a medium relevance compared to other life cycle phases.

The use phase has a low resource intensity for the non-energetic resource category (1 point) and a medium resource intensity for energetic resources in comparison to the other life cycle phases (2 points). The phase of waste treatment is assigned a low resource intensity for both the energetic and non-energetic resource categories (1 point) relative to the other life cycle phases.

\begin{tabular}{|c|c|c|c|c|}
\hline \multicolumn{5}{|c|}{ Hot Spot Analysis of coffee. } \\
\hline \multicolumn{5}{|c|}{ Step 1: Assessing the resource-intensity within each life cycle phase. } \\
\hline Life cycle phase & $\begin{array}{l}\text { Raw } \\
\text { material } \\
\text { procure- } \\
\text { ment }\end{array}$ & Production & Use & $\begin{array}{l}\text { Waste } \\
\text { treatment }\end{array}$ \\
\hline Abiotic materials & 2 & 1 & 1 & 1 \\
\hline Biotic materials & 1 & 3 & 1 & 1 \\
\hline Water & 2 & 1 & 2 & 1 \\
\hline Energy & 3 & 2 & 3 & 1 \\
\hline \multicolumn{5}{|c|}{ Step 2: Assessing the resource-intensity between the different life cycle phases. } \\
\hline $\begin{array}{l}\text { Resource } \\
\text { category }\end{array}$ & $\begin{array}{l}\text { Raw } \\
\text { material } \\
\text { procure- } \\
\text { ment }\end{array}$ & Production & Use & $\begin{array}{l}\text { Waste } \\
\text { treatment }\end{array}$ \\
\hline Non-energetic & 3 & 2 & 1 & 1 \\
\hline Energy & 3 & 2 & 2 & 1 \\
\hline
\end{tabular}

Step 3: Identification of hot spots on the basis of steps 1 and 2.

\begin{tabular}{|l|l|l|l|l|}
\hline \multicolumn{1}{|c|}{ Life cycle phase } & $\begin{array}{l}\text { Raw } \\
\text { material } \\
\text { procure- } \\
\text { category }\end{array}$ & Production & Use & $\begin{array}{l}\text { Waste } \\
\text { treatment }\end{array}$ \\
\hline Abiotic materials & 6 & 2 & 1 & 1 \\
\hline Biotic materials & 3 & 6 & 1 & 1 \\
\hline Water & $\mathbf{6}$ & 2 & 2 & 1 \\
\hline Energy & $\mathbf{9}$ & 4 & 6 & 1 \\
\hline
\end{tabular}

Table IV. Hot Spot Analysis of coffee (based on Kuhndt et al., 2002; Wallbaum and Kummer, 2006) 
To get the picture complete, both parameters of step one and two are multiplied for a better visibility (step three in Table IV). The resource categories abiotic materials, biotic materials and water from step one are multiplied with the evaluation factor ,non-energetic“, the category energy with the factor energy. As a result hot spots are identified. Hot spots are defined as fields with a result of six to nine points. These mark the range where direct action is needed. The identified hot spots for coffee are: the raw material procurement phase in terms of abiotic material (6), water (6) and energy (9) consumption; the production phase concerning biotic material (6) and the energy (6) consumption in the use phase.

\subsection{The Hot Spot Analysis of cream cheese}

An analysis of the "cream cheese-chain" starts necessarily with the cowhusbandry including fodder production. It extends further to the "extraction" of milk, the distribution of cream cheese products, finishing with the consumption and waste treatment of the products. Cream cheese production uses milk as "raw material" to $99 \%$ (Fraunhofer Institute for Process Engineering and Packaging, 1997; Kaiser et al., 2008; Kauppinen et al. 2008b). The transportation processes are not analysed singularly but they are integrated in the respectively following life-cycle phase. Further aspects like agricultural machines or packaging material are considered to be irrelevant compared to the whole life cycle. This applies also for the prevalue chains regarding production of fodder. That means for example that the fodder itself is included in the calculation, the fertiliser to produce the fodder instead is not though the highest energy consumption in the life- 
cycle of milk derives from the production of fertilisers and fodder (Swedish Dairy Association n.d.; Høgaas Eide, 2002). Furthermore this analysis only refers to milk deriving from cows not to such from sheep or goats. Analogue to the example of coffee, results taken from scientific studies will be listed (sub structured in life-cycle phases) and underlined according to their relevance for the resource categories abiotic (A), biotic (B), water (W) and energy (E).

As mentioned earlier, the most important raw material for the production of cream cheese is milk. There are further ingredients like lactic acid bacteria (rennet) as well as salt, herbs, fruits or similar ingredients. Due to their lower relevance at this point compared to milk they will not be considered furthermore (Kuhndt et al., 2002; Wallbaum and Kummer, 2006). The highest resource consumption exists concerning biotic material and water. The material intensity values are: $1,1 \mathrm{~kg} / \mathrm{kg}$ abiotic material; 3 $\mathrm{kg} / \mathrm{kg}$ biotic resources; $31 \mathrm{~kg} / \mathrm{kg}$ water and $0,31 \mathrm{~kg} / \mathrm{kg}$ erosion (Kauppinen et al., 2008b). Energy is used for milking and storage (cooling) of milk products in this life cycle phase.

The phase of production includes the transport of milk, the filtration and the pasteurisation in the processing plant as well as the addition of further ingredients (fruits, herbs, etc.) to the product. The analysis of relevant studies led to a high relevance of the category biotic materials. That is because milk is the most important material in the process. Average relevance was identified for water and energy. In comparison to other activi- 
ties of the food industry, the production phase of milk products is not very energy-intensive (Confederation of the Food and Drink Industry of the EU, 2002; Kauppinen et al., 2008b). Typical energy consumption levels of milk processing are estimated with 0,5 to $1,2 \mathrm{MJ} / \mathrm{kg}$ used milk. A study undertaken by Kraft Jacobs Suchard (KJS) on Philadelphia cream cheese concluded that the major part of fossil primarily energy demand for production is needed outside KJS (Fraunhofer Institute for Process Engineering and Packaging, 1997). According to an environmental declaration of the private cheese factory in Waging am See, energy consumption is one of the most important aspects within this phase (Bergader Privatkäserei, 2004). Regarding water consumption, the production of milk products is comparatively water intensive, because a lot of water is used for cleaning purposes in order to fulfil high hygienic standards. Processes that work relatively efficiently consume 1,3 to 2,31 water per $\mathrm{kg}$ milk. It is even possible to lower the value to 0.8 to 1.01 water per $\mathrm{kg}$ though. During the process phase side products and waste is produced. According to a study of the Fraunhofer Institute, the average losses of raw material in the production process of cream cheese are less than 2\% (Fraunhofer Institute for Process Engineering and Packaging, 1997). Due to that reason waste won't be considered as a relevant fact, because it could even be used as a side product (e.g. fodder). The resource use for packaging that was identified from the Federal Environmental Agency for the use phase is rather relevant for the production phase. This is again relevant for the consumption of abiotic materials though but because preliminary phases of the 
value chain are not considered, this aspect is not relevant for the whole phase (Federal Environmental Agency, 2002).

During the use phase, the transportation of cream cheese from the retailers to the consumer is analysed. The very use phase itself - meaning the consumption of cream cheese by the final consumer - is not connected to any significant environmental impact. The most relevant resource category of that phase derives from the energy consumption but on the whole it is only of average relevance because cooling energy is partially due to the existence of other products in the cooling shelves or fridges. The cooling energy is continuously needed and can vary considerably (Dutilh and Kramer, 2000). Different LCA (Bernhard and Moos, 1998; Svenskmjölk (Swedish Dairy Association) conclude, that energy consumption is important in that phase mostly due to transportation but negligible compared to other phases. Nevertheless the Federal Environmental Agency considers the emissions caused by the transportation and the packaging in that phase as relevant aspects (Federal Environmental Agency, 2002). The emissions point to the relevance of the category energy; packaging is not connected to additional resource consumption and is therefore not analysed furthermore. Regarding the route of transportation of products by consumers a Hungarian study concludes that per household and year about a total distance of 300 to $500 \mathrm{~km}$ is covered for purchasing food (Massari, 2002). Another LCA concludes that the transportation of a product by car plays a rather important role (Diers et al., 1999). The consumption of water is instead less relevant. 
The packaging deriving from cream cheese packages are most relevant in the waste treatment phase. The relevance is rather low because the recycling systems mainly offer a treatment for such packages. But the raw material consumption connected to recycling is not considered here (energy, wastewater, emissions) because the resource intensity is low related to the whole life cycle and per service delivered (200g boxes or a relevant service unit enjoying a slice of bread with cream cheese). Furthermore the waste treatment of product waste that might not be consumed is not considered although the prevention of such product waste would have a noticeable influence on the whole life cycle. The idea behind is that a reduced resource input will lead to several reductions of waste and therefore costs in purchasing, processing and disposal along the whole life cycle chain. Table V summarises the results below:

\begin{tabular}{|l|l|}
\hline Raw material procurement & Relevance \\
\hline All resource categories relevant but highest resource consump- & \\
tion: biotic material and water & \\
\hline Energy is used for milking and storage (cooling) of milk pro- & E \\
\hline ducts & \\
\hline Assigned resource intensity in points for the waste treatment phase: \\
\hline A: 1 , B: 3 , W: 3 , E: 2 & Relevance \\
\hline Production & E \\
\hline Not very energy-intensive & \\
\hline
\end{tabular}


Consumption of water irrelevant

Assigned resource intensity in points for the waste treatment phase:

A: $1, \mathrm{~B}: 1, \mathrm{~W}: 1, \mathrm{E}: 2$

\begin{tabular}{|l|l|}
\hline Waste treatment & Relevance \\
\hline Packaging deriving from cream cheese packages most relevant & - (in Germany) \\
Relevance for Germany rather low: recycling systems offer & \\
treatment for such packages & \\
\hline Assigned resource intensity in points for the waste treatment phase: \\
A: 1 , B: 1 , W: 1 , E: 1
\end{tabular}

Table V. Central results of scientific studies on life cycle aspects of cream cheese, by life cycle phases and with indication of relevance for the resource categories abiotic (A), biotic (B), water (W) and energy (E) (adapted from Kuhndt et al. 2002; Wallbaum and Kummer, 2006)

The studies mentioned above (Høgaas Eide, 2002; Svenskmjölk n.d.; Kauppinen et al., 2008b; Kaiser et al., 2008) conclude that the agricultural production phase is the most resource-intensive one regarding the whole life cycle of cream cheese. Of subordinated relevance is the production as well the use phase - the order of those two can alter though, depending on the point of view. Milk and cream cheese as easily perishable goods need to be cooled during their whole value chain, which makes energy a relevant category. The life-cycle wide relevance of the single phases regarding the resource consumption is assessed in step two of Table VI. The phase of raw material procurement and production proved to be strongly relevant here. In step three, these values are multiplied by the results of step one. 


\begin{tabular}{|l|l|l|l|l|}
\hline \multicolumn{4}{|l|}{ Hot Spot Analysis of cream cheese. } \\
\hline \multicolumn{4}{|c|}{ Life cycle phase 1: Assessing the resource-intensity within each life cycle phase. } \\
\hline $\begin{array}{l}\text { Raw } \\
\text { Resource } \\
\text { category }\end{array}$ & $\begin{array}{l}\text { Production } \\
\text { ment }\end{array}$ & Use & $\begin{array}{l}\text { Waste } \\
\text { treatment }\end{array}$ \\
\hline Abiotic materials & 1 & 1 & 1 & 1 \\
\hline Biotic materials & 3 & 3 & 1 & 1 \\
\hline Water & 3 & 2 & 1 & 1 \\
\hline Energy & 2 & 2 & 2 & 1 \\
\hline
\end{tabular}

Step 2: Assessing the resource-intensity between the different life cycle phases.

\begin{tabular}{|l|l|l|l|l|}
\hline \multicolumn{1}{|c|}{ Life cycle phase } & $\begin{array}{l}\text { Raw } \\
\text { material } \\
\text { procure- } \\
\text { ment }\end{array}$ & Production & Use & $\begin{array}{l}\text { Waste } \\
\text { treatment }\end{array}$ \\
\hline Non-energetic & 3 & 2 & 1 & 1 \\
\hline Energy & 2 & 3 & 2 & 1 \\
\hline \hline
\end{tabular}

Step 3: Identification of hot spots on the basis of steps 1 and 2.

\begin{tabular}{|l|l|l|l|l|}
\hline \multicolumn{1}{|c|}{ Life cycle phase } & $\begin{array}{l}\text { Raw } \\
\text { material } \\
\text { procure- } \\
\text { ment }\end{array}$ & Production & Use & $\begin{array}{l}\text { Waste } \\
\text { treatment }\end{array}$ \\
\hline Abiotic materials & 3 & 2 & 1 & 1 \\
\hline Biotic materials & $\mathbf{9}$ & $\mathbf{6}$ & 1 & 1 \\
\hline Water & $\mathbf{9}$ & 4 & 1 & 1 \\
\hline Energy & 4 & $\mathbf{6}$ & 4 & 1 \\
\hline
\end{tabular}

Table VI. Hot Spot Analysis of cream cheese (adapted from Kuhndt et al., 2002; Wallbaum and Kummer, 2006)

The most important life cycle phases regarding resource intensity are identified. Referring to step three in Table VI based on the scientific results mentioned above, relevant hot spots appear in the raw material procurement phase in terms of biotic materials (9) and water (9) as well as biotic materials (6) and energy consumption (6) during the production phase. The high-energy consumption derives mostly from the constant need of cooling which is relevant for all life-cycle phases. For the fodder con- 
sumption biotic material is most relevant which is accounted in the raw material procurement phase.

\section{Conclusions}

The Hot-Spot-Analysis seems to be a good opportunity for companies to address resource efficiency potentials that are at the same time relatively cost moderate. Several companies have adopted this methodology in their management system in order to define their needs of action. The specific results are confidential because of high importance for competitiveness in their market. Therefore it could be established that the methodology is accepted and used for a first screening step in complex value chains with several stakeholder requirements. The different companies have implemented lots of arrangements that affected the sustainability level positively approved by external experts and stakeholders (Kuhndt et al., 2009). Secondly they often got results that were surprising - for example great difference of resource efficiency rates between similar product chains and same products. Some compared value chains showed differences of a factor four of resource efficiency producing the same product (Kuhndt et al., 2002). Some companies used a sustainability indicator set for estimating the hot spot including social and economic criteria. The methodology gave them the possibility to this and resulted in reliable decisions for example other agricultural methods, social acceptable contracts with land workers, hygienic standards, working conditions etc. The companies used it for strategic management decision concerning designing value chains, electing of suppliers, asking for and helping for more sustainable management in the different process stages. Another important practice was using the 
systematic view on value chains for marketing and communication tools that will position them at the POS. In conclusion: Due to this methodology, companies are able to identify hot spots of resource consumption and other sustainability topics in their product chains in order to take countermeasures. Although the Hot Spot Analysis appears as an instrument applicable for companies of all sizes and budgets, there is still the requirement for understanding and collecting scientific information before performing the analysis. On the other hand, this does not necessarily need to be done by each company itself but could be done, e.g., by branch organisations.

The Hot Spot Analysis is also applicable to the macroeconomic level. This could be relevant for political decision makers, for instance in the context of land use competitions or when developing instruments for promoting sustainable consumption and production.

The Hot Spot Analysis won't substitute the necessity of material intensity analysis or LCA because it only provides indicatory information. The Hot Spot Analysis is even dependent on certain MIPS or LCA studies already done. However, Hot Spot Analysis can help companies in using existing life cycle studies without the continuous need for creating or ordering time- and cost-intensive conventional life-cycle analyses by themselves with their need of a high amount of data or information. For the Hot Spot Analysis presented here the problems of time- and cost-intensity do not apply but it clearly does not substitute a material flow analysis (e.g. MIPS 
analysis) or - as a next step - a detailed LCA. However, the Hot Spot Analysis can provide a foundation for more detailed analyses because it points out relevant needs for action where at first detailed data analyses must follow. Adapted indicator sets for measuring sustainability will help to clarify the situation and result in action points with high potential for sustainability effects.

The examples examined in this paper show that compared to other life cycle phases the extraction is of high importance, which is confirmed by several studies in the food sector. Talve (2001) concludes that in a LCA for beer, Høgaas Eide (2002) and Sevenskmjölk (n.d.) for milk and Moller, Vold et al. (1996) and Carlsson-Kanyama et al. (2001) for meat. Also the use phase can have a high relevance, especially when storage and preparation of food is connected to high energy consumption (cooking, cooling or deep-freezing).

Numerous studies (Baudisch et al., 2004; Hirschfeld et al., 2008; Kaiser et al., 2008; Kauppinen et al., 2008a; Kauppinen et al. 2008b) show that foodstuffs based on animal products are connected to higher resource consumption than those based on vegetable origins. Food that underwent a complex processing (cooling, cooking, baking, heating up, pulverise) is characterised by high-energy consumption in the production, as well as use phase. In case of easily perishable goods, the cooling process needs to be guaranteed for the whole value chain, which leads to an additional energy demand. Waste treatment does not usually play a significant role but the prevention of waste is reflecting on the whole life cycle. While the rel- 
Resource intensity in global food chains: the Hot Spot Analysis

evant processes in the production and use phases seem to be represented well in Hot Spot Analyses of foodstuffs, the relevance of fodder production and the relevance of food waste prevention are aspects that might be underestimated within the system boundaries applied in the case studies of this paper. 


\section{References}

Baudisch, J., Bringezu, S., Schütz, H., Steger, S. (2004), “International

Comparison of resource use and its relation to economic growth: The development of total material requirement, direct material inputs and hidden flows and the structure of TMR.", Ecological Economics, Vol.51 No. 1-2, pp. 97-124.

Bergader Privatkäserei (2004), “Umwelterklärung 2004 der Bergader Privatkäserei $\mathrm{GmbH}^{\prime}$ ("Environmental declaration of the Bergrader private cheese dairy in 2004“), Waging am See.

Bernhard, S. and Moos, T. (1998), “Ökobilanz des Camemberts: Entscheidungsgrundlagen für den umweltbewussten Einkauf von Weichkäse“, Schriftenreihe 2, Dezember 1998, Fachverein Arbeit und Umwelt, FAU ("Ecological balance sheet of the Camembert: Basis of decisions for the ecologically aware purchase of soft cheese", series 2 , December 1998, Profession club employment and environment).

Beucker, S. Busch, T. Müller, A. (2004), “Computer Aided Resource Efficiency Accounting." In: B. Wagner and S. Enzler (Ed.), Material Flow Management - Improving Cost Efficiency and Environmental Performance. Springer-Verlag, Berlin/Heidelberg/New York.

Bundesregierung (2002), "Perspektiven für Deutschland. Unsere Strategie für eine nachhaltige Entwicklung“, Berlin (Federal Government, (2002): "Perspectives for Germany. Our strategies for sustainable development", Berlin), 
Resource intensity in global food chains: the Hot Spot Analysis

available at:

http://64.233.183.132/search?q=cache:WsD3vkNZygkJ:www.dgb.d e/themen/themen_a_z/abisz_doks/n/nachhaltigkeitsstrategie.pdf/vie $\mathrm{w} \% 3$ Fshowdesc\%3D1+Bundesregierung+(2002):+Perspektiven $+\mathrm{f} \%$ $\mathrm{C} 3 \% \mathrm{BCr}+$ Deutschland. + Unsere + Strategie $+\mathrm{f} \% \mathrm{C} 3 \% \mathrm{BCr}+$ eine + nach haltige + Entwicklung, + Berlin $\& \mathrm{hl}=\mathrm{de} \& \mathrm{ct}=\mathrm{clnk} \& \mathrm{~cd}=1 \& \mathrm{gl}=\mathrm{de} \& \mathrm{client}$ =firefox-a (accessed, 8 December 2008).

Carlsson-Kanyama, A., Pipping Ekström, M., Shanahan, H. (2001), "Case studies of life cycle energy use for the Swedish food supply: possibilities for more energy efficient diets", In proceedings of the international conference on LCA in Foods, the Swedish Institute for Food and Biotechnology and Vito, the Flemish Institute for Technological Research, Gothenburg, Sweden, April 26-27 2001, pp. 70-76.

Christopher, M. (1998), "Logistics and Supply Chain Management - Strategies for reducing cost and improving service", Financial Times Professional Ltd., 2nd Edition, Prentice Hall, London.

Commission of the European Communities (CEC) (2003), "Communication from the Commission to the Council and the European Parliament of 18 June 2003 - Integrated Product Policy - Building on Environmental Life-Cycle Thinking” [COM(2003) 302 final, available at: http://eurlex.europa.eu/smartapi/cgi/sga_doc?smartapi!celexplus!pro d!DocNumber\&lg=en\&type_doc=COMfinal\&an_doc=2003\&nu_do $\mathrm{c}=302($ accessed 8 December 2008). 
Resource intensity in global food chains: the Hot Spot Analysis

Confederation of the Food and Drink Industry of the EU (CIAA) (2002), "The EU Food and Drink Industry and the EU Common Agricultural Policy" (1/10/2002), available at:

http://www.ciaa.be/asp/documents/brochures_form.asp?doc_id=11, (accessed 22 December 2008).

Deutscher Kaffeeverband (2005), "Kaffeewissen" (German coffee association, 2005. Coffee knowledge), available at:

http://www.kaffeeverband.de/546.htm (accessed 10.11.2005).

Diers, A., Langowski, H. C. et al. (1999), Produkt-Ökobilanz vakuumverpackter Röstkaffee (Product Life-Cycle Analysis of vacuum packaged coffee), ecomed publishers, Heidelberg.

Dutilh, C. E.and Kramer, K. J. (2000), "Energy Consumption in the Food Chain". Ambio: a journal of the human environment, Vol. 29 No. 2, pp. 98101.

ETC SCP - European Topic Centre on Sustainable Consumption and Pro duction (2009), "Environmental Pressures from European Consumption - A study in integrated environmental and economic analysis”, working paper, ETC/SCP, Copenhagen, January 2009.

EDE (Consulting for Coffee, International Coffee Organization) (2001), "Environmental issues relating to the coffee chain within a context of trade liberalization, through a life-cycle approach", London, available at: http://dev.ico.org/show_document.asp?id=222 (accessed 14 January 2009). 
Resource intensity in global food chains: the Hot Spot Analysis

European Council (2006), "Renewed EU Sustainable Development Strategy",

Brussels, information available at:

http://ec.europa.eu/environment/eussd/ (accessed 8 December 2008).

Federal Environmental Agency (2002), Umweltdaten Deutschland 2002 FE Agency - 2002 - E. Schmidt, Berlin (Environmental facts Germany 2002, FE Agency - 2002 - E. Schmitt, Berlin,

available at: www.umweltdaten.de/publikationen/fpdf-1/2315.pdf (accessed 8 December 2008).

Folkerts, H., Koehorst, H., (1998), "Challenges in international food supply chains: vertical co-ordination in the European agribusiness and food industries", British Food Journal, Vol. 100 No. 8, pp. 385-388, MCB UP Ltd., available at:

http://www.emeraldinsight.com/Insight/viewContentItem.do?conten tType $=$ Article $\&$ contentId $=870449,($ accessed 22 December 2008). 
Fraunhofer Institute for Process Engineering and Packaging ISI/ DIW/ GfK/ IEU/ TUM (publisher) (2004), “Energieverbrauch der privaten Haushalte und des Sektors Gewerbe, Handel, Dienstleistungen (GHD) Abschlussbericht an das Bundesministerium für Wirtschaft und Arbeit, ("Energy consumption of private households and the tertiary sector (trade commerce and services. Summary of the final report to the Federal Ministry of Economics and Labour) Fraunhofer Institut für Systemtechnik und Innovationsforschung, Deutsches Institut für Wirtschaftsforschung, GfK Marketing Services, GfK Panel Services Consumer Research, Institut für Energetik und Umwelt, Lehrstuhl für Energiewirtschaft und Anwendungstechnik an der Technischen Universität München, Projektnr. 17/02, available at:

http://publica.fraunhofer.de/starweb/servlet.starweb?path=pub0.web \&search=N-48881 (accessed 18 January 2009).

Hahlbrock, K. (2009), Feeding The Planet: Environmental Protection through Sustainable Agriculture. Haus Publishing Ltd, London).

Hirschfeld, J. , Weiß, Preidl M., Korbun T. (2008) “Klimawirkungen der Land wirtschaft in Deutschland“, Diskussionspapier des IÖW 66/06, Schriftenreihe des IÖW (Institut für ökologische Wirtschaftsforschung)186/08, Studie im Auftrag von foodwatch e.V. / "Climate effects of agriculture in Germany", discussion paper of the IÖW $66 / 06$, series of the IÖW 186/08, by order of foodwatch e.V. available at: http://www.foodwatch.de/foodwatch/content/e10/e17197/e172 01/e17220/IOEW_Klimawirkungen_der_Landwirtschaft_SR_ 186_08_ger.pdf (accessed 18 January 2009). 
Hoekstra, A.Y., Chapagain, A.K. (2006), "Water footprints of nations:

Water use by people as a function of their consumption pattern", Water Resources Management, Vol. 21 No.1, pp. 35-48.

Høgaas Eide, M. (2002), “Life Cycle Assessment (LCA) of Industrial Milk Production". International Journal of Life Cycle Assessment, Vol. 7 No. 2, pp. 115-126, available at: http://appli1.oecd.org/olis/2001doc.nsf/43bb6130e5e86e5fc12569fa 005d004c/355a756cabe1a5ccc1356bdb00581d53/\$FILE/JT0012844 8.pdf (accessed 12 July 2006).

Huff, J., Türk, V. (2006), "Die Hot-Spot-Analyse“. Unpublished discussion paper. Wuppertal Institute for Climate, Environment and Energy, Wuppertal, ("The Hot Spot Analysis". Unpublished discussion paper. Wuppertal Institute for Climate, Environment and Energy, Wuppertal).

International Organization for Standardization (ISO) 14041, "Environmental management -- Life cycle assessment -- Examples of application of ISO 14041 to goal and scope definition and inventory analysis".

Kaiser, C., Ritthoff, M., Rohn, H. (2008), „Wie viel Natur kostet unsere Nahrung? Ein Beitrag zur Materialintensität ausgewählter Produkte aus Landwirtschaft und Ernährung“. Draft Paper. Wuppertal Institute for Climate, Environment and Energy, Wuppertal ("How much nature does our nurture cost? A contribution to material intensity of selected products of agriculture and nutrition". Draft Paper. Wuppertal Institute for Climate, Environment and Energy, Wuppertal). 
Kauppinen, T.; Lähteenoja, S.; Lettenmeier, M. (2008a), "Data Envelopment Analysis as a Tool for Sustainable Foodstuff Consumption", Sustainable Consumption and Production: Framework for action proceedings, 10-11 March 2008, Brussels, Belgium. Conference of the Sustainable Consumption Research Exchange (SCORE!) Network, available at:

www.score-network.org/files//24119_CF2_session_5.pdf, (accessed 18 January 2009).

Kauppinen, T., Lähteenoja, S., Lettenmeier, M. (2008b), Kotimaisten elintarvikkeiden materiaalipanos - ElintarvikeMIPS. (Material input of Finnish foodstuffs. In Finnish.) Maa- ja elintarviketalous 130. MTT Agrifood Research Finland, Jokioinen.

Kotakorpi, E., Lähteenoja, S., Lettenmeier, M. (2008), ”Household MIPS - Natural resource consumption of Finnish households and its reduction.", The Finnish Environment 43 en, Finnish Ministry of the Environment, Helsinki.

Kuhndt, M., Liedtke, C., Nickel, R., Rohn, H. (1998), ”Applying Material Flow Accounting: Eco-Auditing and Resource Management at the Kambium Furniture Workshop.”, The Journal of Industrial Ecology, Vol.2 No. 3, pp. 131-147, available at: http://www3.interscience.wiley.com/journal/120143731/abstract?C RETRY $=1 \&$ SRETRY $=0$ (accessed 14 December 2008).

Kuhndt, M., et al. (2002), Hot spot analysis in practice - a case study focusing a MNC. Confidential report/project. 
Kuhndt M., et al. (2009), Hot Spot analysis in practice - a case study focusing a MNC. Confidential report/project.

Lähteenoja, S., Lettenmeier, M., Saari, A. (2006), "The natural resource consumption of the Finnish transport system. The Finnish Environment 820en/2006”, Environmental Protection Department, available at: http://www.ymparisto.fi/default.asp?contentid=302035\&lan=en (accessed 14 December 2008).

LCA Food Database: available at: http://www.lcafood.dk/ (accessed 14 December 2008).

Massari, S. (2002), "Current food consumption patterns and global sustainability, UNEP - Sustainable Agri-Food Production and Consumption Forum.”, Discussion paper, available at: www.agrifood-forum.net/issues/consumption/doc/agriconsumption.pdf (accessed 18 January 2009).

Mauser, W. (2009), Water Resources: Efficient, Sustainable and Equitable Use, Haus Publishing Ltd, London.

Mikkola, M. (2008), "Coordinative structures and development of food supply chains", British Food Journal, Vol.110 No 2, pp. 189-205, Emerald Group Publishing Limited, available at: http://emeraldinsight.com/Insight/viewContentItem.do?contentType $=$ Article\&contentId=1662914, accessed 22 December 2008. 
Moller, H., Vold, M. et al. (1996), "Life cycle assessment of pork and lamb meat", paper presented at International conference on application of Life Cycle Assessment in agriculture, food and non-food agro industry and forestry, Brussels, Belgium.

Pagan, R. and Lake, M. (1999) "A whole of life approach to sustainable food production", Industry and Environment, Vol.22 No.2-3, pp.13-17.

Population Division of the Department of Economic and Social Affairs of the United Nations Secretariat (2007) "World Population Prospects: The 2006 Revision and World Urbanization Prospects: The 2007 Revision.", available at: http://esa.un.org/unup/ (accessed 8 December 2008).

Porter, M. E. (1996), Wettbewerbsvorteile: Spitzenleistungen erreichen und behaupten, Frankfurt/Main (Competitive advantage: Achieving top performance and holding,, Frankfurt/Main).

Rice, P.D., McLean, J., (1999), "Sustainable Coffee at the Crossroads - Consumer's Choice Council, Canada", White paper, available at: http://66.102.1.104/scholar?hl=de\&lr=\&client=firefox$\mathrm{a} \& \mathrm{q}=$ cache:EXo5cS0NqQJ:www.greenbeanery.ca/bean/documents/sustainableCoffee. pdf + sustainable + coffee + at + crossroads + Rice + and + Mc + Lean $\quad$ (accessed 18 January 2009).

Rimmington, M., Carlton Smith, J., Hawkins, R. (2006), "Corporate social responsibility and sustainable food procurement", British Food Journal, Vol. 108 No. 10, pp. 824-837, Emerald Group Publishing Limited, available at: 
Resource intensity in global food chains: the Hot Spot Analysis

http://emeraldinsight.com/Insight/viewContentItem.do?contentType

$=$ Article\&contentId=1575641, accessed (22 December 2008).

Ritthoff, M., Liedtke, C., Rohn, H. (2002), “Calculating MIPS. Resource productivity of products and services", Wuppertal Special 27 e,

available

at:

www.wupperinst.org/de/publikationen/entnd/index.html?\&beitrag_i $d=716 \& b i d=85$ (accessed 8 December 2008).

Schätzl, L. (2000), Wirtschaftsgeographie 2. Empirie. Schöningh, Paderborn, (Economic geography 2. Empiricism. Schöningh, Paderborn).

Schary, P.B., Skjoett-Larsen, T. (2001), Managing the Global Supply Chain, 2nd Edition, Copenhagen Business School Press, Copenhagen.

Schmidt-Bleek, F. (2009), The Earth: Natural Resources and Human Intervention, Haus Publishing Ltd, London.

Seuring, S., Westhaus, M. (2002), "Supply Chain Controlling. Ziel und funktionsorientierte Konzeption.“, Diskussionspapier Nr. 04, Supply Chain Management Center, Oldenburg ("Supply Chain Controlling. Aim and function oriented conception", discussion paper No 04, Supply Chain Management Center, Oldenburg).

Svenskmjölk (Swedish Dairy Association) (n.d.), "Milk and the Environment", Swedish Dairy Association, available at: http://www.svenskmjolk.se/ImageVault/Images/id_153/scope_128/I mageVaultHandler.aspx (accessed 8 December 2008). 
Talve, S. (2001), “Life Cycle Assessment of a Basic Lager Beer”, Department of Environmental Engineering, Tallinn Technical University, The International Journal for Life Cycle Assessment, Vol. 6 No. 5, pp. 293-298.

Wallbaum, H., Kummer, N., (2006), "Entwicklung einer Hot-Spot-Analyse zur Identifizierung der Ressourcenintensitäten in Produktketten und ihre exemplarische Anwendung.“, Wuppertal Institut, für Klima, Umwelt, Energie und triple innova. AP2.2., Paper des Wuppertal Instituts für Klima, Umwelt, Energie und triple innova: Endbericht im Rahmen des Projektes: "Steigerung der Ressourcenproduktivität als Kernstrategie einer nachhaltigen Entwicklung" im Auftrag des BMBF, Wuppertal ("Development of the Hot Spot Analysis for an identification of resource intensity in product chains and their application in show cases“, Wuppertal Institute for Climate, Environment and Energy and triple innova, AP2.2, paper of the Wuppertal Institute for Climate, Environment and Energy and triple innova: Final report for the project "Augmentation of resource productivity as core strategy for sustainable development" by order of BMBF, Wuppertal).

Wolters, T. et al. (2001), "Sustainable production methods in the coffee chain as a strategy to gain competitive advantage: With special references to a Costa Rican case", paper presented at the Ninth International Conference of the Greening of Industry 2001, Thailand.

World Watch Institute (2006), State of the World 2006: Special Focus: China and India. World Watch Institute, Washington.

WRI, UNDP (1998), World Resources Institute/ United Nations Development 
Resource intensity in global food chains: the Hot Spot Analysis

Programme et al. (1998), World Resources 1998-99. A guide to the global environment, Oxford University Press, Oxford. 